\title{
The Relationship Between Adequacy of Animal Protein Consumption and Hemoglobin Levels for Pregnant Women
}

\author{
${ }^{1 *}$ Dian Fera, ${ }^{2}$ Maiza Duana, ${ }^{3}$ Enda Silvia Putri \\ ${ }^{1}$ Faculty of Public Health, Teuku Umar University, Meulaboh, Indonesia, dianfera@utu.ac.id \\ ${ }^{2}$ Faculty of Public Health, Meulaboh, Indonesia, maizaduana@utu.ac.id \\ ${ }^{3}$ Faculty of Public Health, Teuku Umar University, Meulaboh, Indonesia, endasilviaputri@utu.ac.id \\ *Coresponding Author: Dian Fera, e-mail: dianfera@utu.ac.id
}

\section{ABSTRACT}

Adequacy of nutrition is needed by a person from the womb to adulthood. Pregnant women are one of the groups of people who are prone to malnutrition. One of the nutritional problems in pregnant women is iron anemia $(\mathrm{Fe})$. Pregnant women are said to be anemic if their $\mathrm{Hb}$ level is $<11 \mathrm{~g} / \mathrm{dl}$, anemia can also occur due to an increased need for a person's body, for example during menstruation, pregnancy and childbirth, while the iron that enters is only a little, it is highly recommended to consume food that comes from animal protein such as fish., meat, eggs and milk. examine the relationship between the adequacy of animal protein consumption on hemoglobin $(\mathrm{Hb})$ levels of pregnant women in Puskesmas Johan Pahlawan Aceh Barat.Methods: This study is a quantitative study with a cross-sectional design. The population in this study were all pregnant women in the second and third trimesters who were recorded at Puskesmas Johan Pahlawan and Suak Ribee, West Aceh district in February 2020, totaling 165 people, the sampling technique used the purposive sampling method using the Slovin formula with a sample of 62 people. The results showed that there was a significant relationship between the consumption of animal protein intake and hemoglobin levels in pregnant women with a $\mathrm{p}$ value $=0.022$. In conclusion, the $\mathrm{HB}$ level of pregnant women who consume enough animal protein is more normal than pregnant women who do not consume enough animal protein.
\end{abstract}

\section{ARTICLE INFORMATION}

\author{
Submitted: $16 / 03 / 2021$ \\ Revised: 05/05/2021 \\ Accepted: 17/05/2021 \\ Publish Online: 26/05/2021
}

\author{
Keywords: \\ Animal Protein \\ Hemoglobin Levels \\ Pregnant Women
}

How to cite this article: Fera, D., Duana, M., Putri, E. S. (2021). The Relationship Between Adequancy of Animal Protein Consumption and Hemoglobin Levels for Pregnant Women. JNS: Journal of Nutrition Science, 2 (1), 1-6

\section{Introduction}

Quality humans are very much determined by nutritional status. Physical growth and intelligence development will be disrupted if they are malnourished. Since in the womb until adulthood, nutritional adequacy is very necessary (Yuliati et al., 2017). Pregnant mother is one of them community groups are prone to experiencing malnutrition, iron anemia is one of the nutritional problems in pregnant women (WHO, 2011; Ministry of Health, 2014). Anemia problem is a syringe in pregnant women. The prevalence of anemia increases in pregnancy from the second trimester to the third trimester by 2 to 3 times, the nutritional status of the mother is measured through the upper arm circumference (LILA) which provides nutritional reserves and the nutritional status of the mother in pre-pregnancy (Karouglu et al, 2010). Pregnant women are said to be anemic if their $\mathrm{Hb}$ level is <11 gr / dl (WHO, 2011; Ministry of Health, 2014).

In general, food consumption is closely related to nutritional status, if the food consumed has good nutritional value, then the nutritional status is also good, on the other hand, if the food consumed lacks nutritional value, it can cause malnutrition (Yuliati et al, 2017). Therefore pregnant women must consume energy and consume sources of iron derived from animal protein, not below the nutritional adequacy rate (RDA) (Setyawati and Syauqi, 2014). The occurrence of anemia is because the level of $\mathrm{Hb}$ in the blood is lower than the normal limit, anemia can 
also occur due to an increase in the need for a person's body, for example during menstruation, pregnancy and childbirth, while the iron that enters is only a little (Ministry of Health, 2013).

Protein is one of the nutrients needed by the body, especially for building cells and tissues, maintaining and maintaining the body's resistance, helping the formation of enzymes, hormones and various other biochemical substances, thus lack of protein intake will affect various body conditions needed to survive. healthy (Syatriani and Aryani, 2010). The need for protein during pregnancy will increase for fetal growth and to maintain maternal health. It is highly recommended to consume foods derived from animal protein such as fish, meat, eggs and milk (Kemenkes RI, 2014). Because animal protein contains 20 types of complete and easily digested amino acid elements to meet the nutritional needs of mothers during pregnancy (WHO / FAO / UNU, 2007; Elango, 2016).

The results of basic health research by the Ministry of Health Research and Development Agency of the Republic of Indonesia in 2013, the prevalence of anemia in the population of pregnant women was $37.1 \%$, while the results of basic health research by the Indonesian Ministry of Health Research and Development Agency in 2018 the prevalence of anemia in the population of pregnant women increased, namely by $48.9 \%$, Anemia cases of pregnant women in Aceh province in 2017 were $38.6 \%$, (Aceh Provincial Health Office), while cases of anemia in pregnant women in West Aceh Regency in 2019 were $30.67 \%$, Puskesmas Johan Pahlawan pregnant women suffering from anemia $36.54 \%$, Puskesmas Suak Ribee amounted to $70.68 \%$. (West Aceh Health Office, 2019).

A preliminary study conducted by researchers with interviews with 10 pregnant women in West Aceh district about the food they consume where only 4 pregnant women have enough animal protein, and 6 people do not have enough animal protein consumption, where ideally pregnant women should consume foods containing protein. adequate and balanced nutrition and must be twice or one portion more than the amount of food consumption of women before pregnancy (Almatsier, 2010; Ministry of Health, 2016). From the above background, the researcher is interested in making a study of the relationship between consumption of animal protein and hemoglobin levels of pregnant women in Johan Pahlawan sub-district, West Aceh district.

\section{Method}

This research was conducted in two health centers all of these words must be replaced with puskesmas in Johan Pahlawan sub-district, West Aceh district including Johan Pahlawan and Suak Ribee Puskesmas. This research was conducted from April to June 2020. The equipment and materials used in this study were questionnaire form by means of interviews and direct observation with respondents. This research is a quantitative study with a cross sectional design. This study was to determine the closeness of the relationship between consumption of animal protein and hemoglobin levels of pregnant women.

The population in this study were all pregnant women in the second and third trimesters who were registered at the Johan Pahlawan Puskesmas and Puskesmas Suak Ribee, Johan Pahlawan District, West Aceh Regency in February 2020, totaling 165 people. The samples in the study were all pregnant women in the second and third trimesters who were recorded at the Johan Pahlawan Health Center and the Suak Ribee Health Center Puskesmas, Johan Pahlawan District, West Aceh Aceh Barat Regency in February 2020 using the Slovin formula (Notoatmodjo, 2010) so that a sample of 62 people was obtained. The inclusion criteria were all pregnant women in the second and third trimesters who were willing to be respondents, and did not suffer from blood disorders. The sampling technique used purposive sampling method, namely sampling based on special criteria. The data will be analyzed using correlation test and logistic regression.

\section{Results \\ Univariate Analysis of Adequacy Level of Animal Protein Consumption}

The results of the observation of the frequency distribution of the animal protein adequacy level of pregnant women were divided into two categories, namely mothers who had sufficient levels of animal protein adequacy and mothers who had sufficient levels of animal protein. Adequacy of animal protein is not sufficient. In Table 1, it can be seen that the distribution of respondents who do not consume enough animal protein intake is twice as large, namely $67.7 \%$ than the respondents who consume enough animal protein intake, which is only $32.3 \%$. 
Table 1.Frequency Distribution of Animal Protein Adequacy Variables

\begin{tabular}{cll}
\hline $\begin{array}{c}\text { Adequate } \\
\text { consumption } \\
\text { of animal } \\
\text { protein }\end{array}$ & Frequency & Percentage \\
\hline Higher & 20 Person & \\
Lower & 42 Person & 67,3 \\
Total & 62 Person & 100 \\
\hline
\end{tabular}

\section{Univariate Analysis of Hemoglobin Levels for Pregnant Women}

The results of the observation of the frequency distribution of maternal hemoglobin levels were divided into two categories, namely mothers who had normal $\mathrm{Hb}$ levels and mothers who had abnormal $\mathrm{Hb}$ levels. In Table 2, it can be seen that the distribution of respondents with abnormal hemoglobin levels is higher, namely $51.6 \%$ of respondents whose hemoglobin levels are normal, namely $48.4 \%$.

Table 2. Frequency Distribution of Respondents Hemoglobin Levels

\begin{tabular}{lll}
\hline $\begin{array}{l}\text { Hemoglobin levels } \\
\text { of pregnant women }\end{array}$ & Frequency & Percentage \\
\hline Normal & 30 Person & 48,4 \\
Abnormal & 32 Person & 51,6 \\
Total & 62 Person & 100 \\
\hline
\end{tabular}

The results of the observation of the frequency distribution of the adequacy of the consumption of animal protein intake of mothers who have sufficient animal protein intake and mothers who have insufficient animal protein intake to normal hemoglobin levels and abnormal hemoglobin levels. Based on Table 3, it shows that the proportion of respondents who consume enough animal protein intake has normal hemoglobin levels, which is $70 \%$ higher than respondents who do not consume enough animal protein intake, their hemoglobin levels are normal, namely $38.1 \%$, while the proportion of respondents who do not consume enough animal protein intake hemoglobin levels abnormal, namely $61.9 \%$, greater than the respondents who had sufficient consumption of animal protein intake, the hemoglobin level was not normal, namely $30 \%$.

OR value $=3,792$ which means that respondents who do not consume enough animal protein intake are almost 4 times more likely to have abnormal hemoglobin levels compared to respondents who consume enough animal protein intake and consume animal protein intake is a risk factor for abnormal hemoglobin levels, from the results of statistical tests with a $95 \%$ degree of confidence also illustrates that there is a close relationship between consumption of animal protein intake and $\mathrm{Hb}$ levels in pregnant women with $\mathrm{p}$ value $=0.022$.

\section{Bivariate Analysis of Adequacy of Animal Protein Consumption with Hemoglobin Levels of Pregnant Women}

Table 3. The Relationship between Adequacy Level of Animal Protein Consumption and Hemoglobin Levels for Pregnant Women

\begin{tabular}{|c|c|c|c|c|c|c|c|c|}
\hline \multirow{3}{*}{$\begin{array}{l}\text { Adequacy level of } \\
\text { animal protein }\end{array}$} & \multicolumn{6}{|c|}{ hemoglobin levels of pregnant women } & \multirow[t]{3}{*}{ OR } & \multirow[t]{3}{*}{$P$ value } \\
\hline & \multicolumn{2}{|c|}{ Normal } & \multicolumn{2}{|c|}{ Tidak normal } & \multicolumn{2}{|c|}{ Total } & & \\
\hline & $\mathbf{F}$ & $\%$ & $\mathbf{F}$ & $\%$ & $\mathbf{F}$ & $\%$ & & \\
\hline Lower & 16 & 38,1 & 26 & 61,9 & 42 & 100 & 3,792 & 0,022 \\
\hline Higher & 14 & 70 & 6 & 30 & 20 & 100 & & \\
\hline
\end{tabular}

\section{Discussion}

Univariate Analysis of Adequacy of Animal Protein Consumption

From 62 respondents, it is known that pregnant women who consume enough animal protein are $32.3 \%$, this number is still very low. During pregnancy, the need for protein increases, this is due to the growth of the fetus (Elango and Ball, 2016). To maintain immunity, pregnant women are encouraged to consume food sources of animal protein, including fish, meat, eggs and milk (Ministry of Health, 2014). During pregnancy it is recommended to consume side dishes containing 40 grams of animal protein obtained from chicken, meat and fish (one of which) is equivalent to 1 medium piece of chicken or 2 small pieces of meat or $1 / 3$ medium fish for 1 serving. food that is eaten per meal 1 plate of rice (200 grams) and it is recommended to eat $4-5$ servings per day, it is 
also recommended to consume 1 boiled egg equal to 55 grams and 1 to 2 glasses of pregnant milk equal to 100 to 200 grams per day (Almatsier , 2009; Sulistyoningsih, 2011: Ministry of Health, 2014).

This study is in line with the results of Azizah and Adriani (2017) where it was found that pregnant women who consumed enough protein were $18.2 \%$. According to the assumptions of researchers in the Johan Pahlawan sub-district, West Aceh Regency, there are fewer pregnant women who consume enough animal protein because most pregnant women do not know the benefits of animal protein.

\section{Univariate Analysis of Hemoglobin Levels for Pregnant Women}

From 62 respondents, it is known that pregnant women who suffer from anemia with $\mathrm{Hb}$ levels $<11 \mathrm{~g} / \mathrm{dl}$ are $51.6 \%$. This illustrates Johan Pahlawan District, West Aceh Regency, pregnant women who suffer from anemia are still high. The negative impact of the high prevalence of anemia is the increase in mortality rates for mothers and children who are born. As a result of disruption in the growth of body cells and brain cells will affect the quality of human resources born as a whole (Ministry of Health, 2014).

This study supports the results obtained by Wiraprasidi et al (2017) where pregnant women who suffer from anemia with abnormal hemoglobin levels are found to be $94.1 \%$. Previously, Sugiarsih and Wariyah (2013) also found that pregnant women suffering from anemia with abnormal hemoglobin levels were $54.6 \%$. According to the assumptions of researchers in Johan Pahlawan sub-district, West Aceh Aceh Barat district, more pregnant women suffer from anemia with abnormal hemoglobin levels because most pregnant women do not consume enough iron $(\mathrm{Fe})$ tablets and foods containing protein and nutrients that can prevent anemia.

\section{Bivariate Analysis of Adequacy of Animal Protein Consumption with Hemoglobin Levels of Pregnant Women}

This study is in line with the results of Yuliati et al. (2017) stated that there is a relationship between the protein adequacy rate and the hemoglobin level of pregnant women with a statistical test of $\mathrm{p}$-value $=$ 0.005 . Previous research conducted by Nurhidayati and Hapsari (2014) also suggested that there was a significant relationship between the nutritional adequacy rate and the hemoglobin level of pregnant women with the statistical test of the value of Pvalue $=0,000$. Previously, Syatriani and Aryani (2010) stated that there was a relationship between the protein adequacy rate and the incidence of anemia in pregnant women, the statistical test, the value of $\mathrm{P}$ value $=0.000$.

To achieve optimal maternal nutritional status, nutritional management of pregnant women must be carried out so that the mother is safe in carrying out her pregnancy and gives birth to healthy babies both physically and mentally. Pregnancy problems will occur if there are certain kinds of nutrients that are not sufficiently fulfilled (Proverawati \& Asfuah, 2017). During pregnancy, the mother undergoes various physiological changes, protein plays an important role in the formation and maintenance of cells that support fetal growth and also plays a role in the growth of plasma and amniotic fluid (amniotic fluid). If the need for protein is insufficient, it will have an impact on the inhibition of placental growth.

Protein has a role in tissue formation and cell regeneration, especially for breast cells, uterus and plasma volume which increases by up to $50 \%$. Protein can be a food reserve that is used for preparation for childbirth, the period after giving birth and during breastfeeding (Fikawati et al., 2014). The absorption of non-heme iron sources contained in plant foods is less than the heme iron sources contained in animal foods (Skolmowska and Glabska, 2019).

According to the assumptions of researchers, why the intake of animal protein has a relationship with $\mathrm{Hb}$ levels because the type of food sources of vegetable protein is consumed more often because the price is cheaper than protein derived from animal sources such as meat which contains lots of iron. Consuming adequate animal protein according to nutritional needs can increase the absorption of iron in the body, so that anemia can be prevented.

\section{Conclusion}

Based on the results of research conducted in the Johan Pahlawan Subdistrict, West Aceh Regency in 2020 , it can be concluded that the HB level of pregnant women who consume enough animal protein is more normal than pregnant women who do not consume enough animal protein, so there is a relationship between the adequacy of animal protein 
consumption and maternal hemoglobin levels. Pregnant.

\section{Acknowledgement}

The author's gratitude goes to the head and staff of the Health Office, the head and staff of the puskesmas Johan Pahlawan and Suak Ribe and all pregnant women who participated in this research.

\section{Author Contribution and Competing Interest}

The author's contribution to this research includes designing a research project, collecting data or analyzing results, being involved in the preparation or revision of scientific papers.

\section{References}

Almatsier S., (2009). Prinsip Dasar Ilmu Gizi. : PT Gramedia Pustaka Utama, Jakarta.

Azizah A dan M Adriani., (2017). Tingkat Kecukupan Energi Protein Pada Ibu Hamil Trimester Pertama Dan Kejadian Kekurangan Energi Kronis. Media Gizi Indonesia, 12 (1): 21-26.

Dinas Kesehatan Provinsi Aceh (2017)., Profil Dinas

Kesehatan. Provinsi Aceh

Dinas Kesehatan Kabupaten Aceh Barat (2018), Profil Dinas Kesehatan. Kabupaten Aceh Barat.

Elango R And R O Ball. (2016). Protein And Amino Acid Requirements During Pregnancy. American Society For Nutrition. 7: 839S844S.

Fikawati S, A Syafiq, R P Purbaningrum, K Karima.,(2014). Energy Consumption of Lactating Mothers: Current Situation and Problems. Makara J. Health Res., 18 (2): 5864.

Karaoglu L., E. Pehlivan, M. Egri, C. Deprem, G. Gunes, M.F. Genc, and I. Temel. (2010). The prevalence of nutritional anemia in pregnancy in an east Anatolian province, Turkey. BMC Public Health. 10:329: 1-12.

Kementerian Kesehatan RI. (2013)., Peraturan Menteri Kesehatan Republik Indonesia Nomor 75 Tentang Angka Kecukupan Gizi Yang Dianjurkan Bagi Bangsa Indonesia.

Kementerian Kesehatan RI., (2013). Riset Kesehatan Dasar Badan Pusat Penelitian dan Pengembangan kesehatan (Puslitbangkes).
Kementerian Kesehatan RI., (2014). Tentang Pelayanan Kesehatan Masa Sebelum Hamil, Masa Hamil, Persalinan, Dan Masa Sesudah Melahirkan, Penyelenggaraan Pelayanan Kontrasepsi, Serta Pelayanan Kesehatan Seksual. Permenkes nomor 97.

Kementerian Kesehatan RI., (2016). Buku Kesehatan Ibu dan Anak, Direktorat Jenderal Bina Kesehatan Masyarakat, Jakarta.

Kementerian Kesehatan RI., (2018). Riset Kesehatan Dasar Badan Pusat Penelitian dan Pengembangan kesehatan (Puslitbangkes).

Notoatmodjo S., (2010). Metodologi Penelitian Kesehatan. Rineka Cipta, Jakarta.

Nurhidayati A dan E Hapsari., (2014). Hubungan Asupan Nutrisi Dengan Kadar Hb Pada Ibu hamil Di BPS Suratini Suwarno Surakarta. Jurnal Kesmadaska. 5 (1): 22-27.

Proverawati A (2011). Anemia dan anemia kehamilan. Nuha Medika. pp: 119. Yogyakarta.

Proverawati A dan S.Asfuah. (2017). Buku Ajar Gizi Untuk Kebidanan. Cetakan Kedua Nuha Medika, Yogyakarta.

Setyawati B., dan A. Syauqy. (2014). Perbedaan asupan protein, zat besi, asam folat, dan vitamin b12 antara ibu hamil trimester III anemia dan tidak anemia di puskesmas tanggungharjo kabupaten grobogan. Journal of Nutrition College. 3(1): 228-234.

Skolmowska D. and Głąbska D., (2019). Analysis of Heme and Non-Heme Iron Intake and Iron Dietary Sources in Adolescent Menstruating Females in a National Polish Sample, Nutrients. 11(5): 1-21.

Sugiarsih U dan Wariyah., (2013). Hubungan Tingkat Sosial Ekonomi Dengan Kadar Haemoglobin. Jurnal Kesehatan Reproduksi; 4 (2): 86-92.

Syatriani S., dan A. Aryani. (2010). Konsumsi makanan dan kejadian anemia pada siswi salah satu smp di kota makassar. Kesmas. 4 (6): 251-254.

World Health Organization. (2011)., Haemoglobin concentrations for the diagnosis of anaemia and assessment of severity: Department of Nutrition for Health and Development (NHD). Geneva.

WHO.,FAO.,UNU. (2007). Protein and amino acid requirements in human nutrition. Report of a joint WHO/FAO/UNU Expert Consultation. 
World Health Organization Tech Rep Ser 2007;935:103-33

Wiraprasidi I.P., Kawengian S.E. dan Mayulu N. (2017)., Faktor-faktor yang berhubungan dengan kadar hemoglobin pada ibu hamil di Puskesmas Lolak, eBiomedik, 5 (2): 1-13.

Yuliati H., L. Widajanti, dan R. Aruben. (2017). Hubungan tingkat kecukupan energi, protein,
besi,Vitamin c dan suplemen tablet besi dengan kadar Hemoglobin Ibu hamil trimester II dan III (di wilayah kerja puskesmas purwanegara 2 kabupaten banjarnegara). JKM. 5(4): 675-682. 